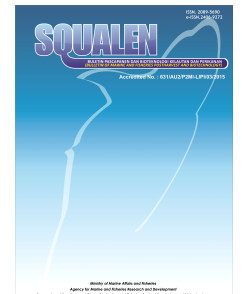

\title{
PURIFICATION AND CHARACTERIZATION OF TRANSGLUTAMINASE FROM LOCAL Streptomyces sp. TTA 02 SDS 14
}

\author{
Lia Siti Nur'amaliyah', Dewi Seswita Zilda" ${ }^{* 2)}$, and Nisa Rachmania Mubarik' \\ ${ }^{1}$ Study Program of Biotechnology, Bogor Agricultural University, Jalan Raya Dramaga Kampus IPB, \\ Bogor, 16680, Indonesia; \\ ${ }^{2}$ Research and Development Center for Marine and Fisheries Product Competitiveness and Biotechnology, \\ Jalan K.S. Tubun Petamburan VI, Jakarta, 10260, Indonesia \\ Article history: \\ Received: 10 August 2016; Revised: 30 October 2016; Accepted: 29 November 2016
}

\begin{abstract}
Streptomyces sp. TTA 02 SDS 14 is a transglutaminase producing bacteria which previously had been screened along with more than one hundred isolates. This research aimed to purify and characterize transglutaminase from this strain. Transglutaminase was purified from crude enzyme by ultrafiltration, Q-Sepharose ion exchange chromatography and Sepacryl S200 size exclusion chromatography sequentially, obtaining yield and purification fold of $1.36 \%$ and 27 folds, respectively. The molecular weight of the purified transglutaminase was $72 \mathrm{kDa}$ detected by zymogram gel electrophoresis. The optimum temperature and $\mathrm{pH}$ were $50^{\circ} \mathrm{C}$ and 6 . The transglutaminase was stable at $45^{\circ} \mathrm{C}$ and could be activated in the presence of $5 \mathrm{mM}$ and $10 \mathrm{mM}$ of $\mathrm{Na}^{+}, \mathrm{K}^{+}, \mathrm{Li}^{+}, \mathrm{Ca}^{2+}, \mathrm{Mg}^{2+}$, BPB $(4-$ bromo-phenacyl bromide), and IAA (iodo acetamide acid), but the activity was inhibited by the presence of $\mathrm{Cu}^{+}, \mathrm{Zn}^{2+}$, and PMSF (phenyl methyl sulfonyl fluoride).
\end{abstract}

Keywords: Streptomyces sp., transglutaminase, purification, characterization, zymogram

\section{Introduction}

Transglutaminase (EC 2.3.2.13; protein-glutamine$\gamma$-glutamyltransferase) catalyzes an acyl transfer reaction using peptide-bond glutamine residues as acyl donors and several primary amines as acceptors. When the $\varepsilon$-amino groups of the protein-bond lysine residues are present as acyl receptors, this enzyme is capable of forming intra and intermolecular $\varepsilon-(\gamma$-Glu)Lys isopeptide bonds (Mahmood, 2013).

Transglutaminases are found in mammalian tissues, plasma, fish, and plants (Pasternack et al., 1998). Unlike TGase from mammalian which are $\mathrm{Ca}^{2+}$ dependent, TGase produced by microorganisms (MTGase) are not. Ando et al. (1989) was the first who reported that strains from the genus Streptoverticillium, which were screened from several thousand microorganisms, had the ability to produce transglutaminase. The use of microorganisms for the transglutaminase production has several advantages, such as easily manufactured on a large scale, relatively short production time and could be continuously produced at a relatively low cost.
Microbial transglutaminase is generally found in actinomycetes, such as Streptoverticillium or genus Streptomyces. The enzyme obtained from microbial fermentation has been applied in the treatment of food of different origins. Extracellular transglutaminase was successfully purified from cultural filtrate of Streptoverticillium mobaraensis (Schmidt, Adolf, \& Fuchsbauer, 2008), Streptoverticillium sp. (Ando et al., 1989), and Streptoverticillium ladakanum (Ho, Leu Hsieh, \& Jiang, 2000; Tsai, Lin \& Jiang, 1996). Intracellular transglutaminase was also found in Bacillus subtilis (Ramanujam \& Hageman, 1990) and Physarum polycephalum (Klein, Guzman, \& Kuehn, 1992).

Transglutaminase has great potential for food protein modification. The enzyme is commonly used in the food industry as a crosslinking agent (Zhang, Zhu, \& Chen, 2009). Some applications of transglutaminase in fish processing are to increase the hardness of fish paste as well as to restructure fish products (Tellez-Luis, Uresti, Ramirez, \& Vazquez, 2002) and to improve gell strength and elasticity of fish products (Srianta, 2000). The use of

\footnotetext{
${ }^{*}$ Corresponding author.

E-mail: seswitazilda@gmail.com

Copyright (C) 2016, Squalen BMFPB. Accreditation Number: 631/AU2/P2MI-LIPI/03/2015.

DOI: http://dx.doi.org/10.15578/squalen.v11i3.234
} 
transglutaminase in fish meat processing could add the values of low economic fish by transforming them into processed products with high sale value.

The invention of new local transglutaminase producing microorganisms will create opportunities for domestic industry to produce transglutaminase using low price local raw material, which eventually will generate competitive transglutaminases to those currently supplied as imported products. The use of transglutaminase produced by domestic industry will reduce the production cost thus resulting products with affordable price. The experiments related to screening, searching of MTGase genes and medium optimization using local isolate, Streptomyces sp. TTA 02 SDS 14 (Fawzya et al., 2016; Seprianto et al., 2016) had been done. This paper reports the results of purification and activity of transglutaminase produced by Streptomyces sp. TTA 02 SDS 14 as well as characteristics of the purified enzyme.

\section{Material and Methods}

\subsection{Microorganism}

Streptomyces sp. TTA 02 SDS 14 previously collected by Research Center for Biotechnology Indonesian Institute of Sciences (LIPI) was used in this study. The strain was isolated from savana soil of Tambora Mount, West Nusa Tenggara, Indonesia.

\subsection{Crude Enzyme Preparation}

The TTA 02 SDS 14 strain was cultivated in petri dishes containing media as reported by Bahrim, lancu, Butu \& Negoita (2010) (peptone water $1.5 \%$, $\mathrm{MgSO}_{4} \cdot 7 \mathrm{H}_{2} \mathrm{O} 0.1 \%, \mathrm{KH}_{2} \mathrm{PO}_{4} 0.2 \%, \mathrm{Na}_{2} \mathrm{HPO}_{4} 0.5 \%$, soybean flour $2 \%$, potato flour $2 \%$, glucose $1.5 \%$ and agar $2 \%$ ) for 6 days at $25^{\circ} \mathrm{C}$. One cylinders $(1 \mathrm{~cm})$ of isolate from solid medium were inoculated into a 50 $\mathrm{mL}$ erlenmeyer flask containing $20 \mathrm{~mL}$ of liquid media adjusted to $\mathrm{pH} 6.0$ and incubated at $25^{\circ} \mathrm{C} 125 \mathrm{rpm}$ for 6 days in an orbital shaker before being used as starter. Ten \% (v/v) of starter was inoculated into 50 $\mathrm{mL}$ erlenmeyer flask with $20 \mathrm{~mL}$ of production medium. Sixty inoculation flasks were prepared to obtain $1 \mathrm{~L}$ of crude enzyme. The culture was harvested after 5 days incubation and then centrifugated at $9,000 \times \mathrm{g}$ (Beckman Coulter ${ }^{\mathrm{TM}}$ ) for $30 \mathrm{~min}$ at $4{ }^{\circ} \mathrm{C}$. The supernatant was collected and stored for further analysis.

\subsection{Purification of Transglutaminase}

The supernatant obtained was concentrated using 10.000 NMWC ultrafiltration (Watson Marlow 323). The concentrated transglutaminase was then applied on a $1.6 \mathrm{~cm} \times 10 \mathrm{~cm}$ Q-Sepharose ${ }^{\mathrm{TM}}$ Fast Flow column (Pharmacia Biotech) previously equilibrated with 0.1 $\mathrm{M}$ citrate buffer ( $\mathrm{pH}$ 6.0). The fraction samples were eluted with $1 \mathrm{M}$ sodium chloride in similar buffer at a flow rate of $2.0 \mathrm{~mL} / \mathrm{min}$, and the active fractions were then collected. The active fraction obtained from the Q-Sepharose ${ }^{\mathrm{TM}}$ Fast Flow column was then applied to $1 \mathrm{~cm} \times 60 \mathrm{~cm}$, High Resolution, Sepacry ${ }^{\mathrm{TM}} \mathrm{S}-200$ column (Pharmacia Biotech) equilibrated with $0.1 \mathrm{M}$ citrate buffer $(\mathrm{pH} \mathrm{6.0)}$ ) at flow rate of $0.5 \mathrm{~mL} / \mathrm{min}$. The active fractions were collected and then measured for their transglutaminase activity, protein concentration and zymogram before finally characterized.

\subsection{Characterization of Transglutaminase}

\subsubsection{Optimum $p H$}

The enzyme activity was measured at different $\mathrm{pH}$ value ranging from 4-9 using $0.2 \mathrm{M}$ citrate buffer $(\mathrm{pH}$ 4-6), 0.2 M phosphate buffer (pH 6-8), $0.2 \mathrm{M} \mathrm{Tris-HCl}$ buffer (pH 8-9) (El-Hofi, Ismail, Nour, \& Ibrahim, 2014). Incubation temperature of enzyme and substrate was carried out at $50^{\circ} \mathrm{C}$ for 60 min which was optimum temperature of crude enzyme as reported by Prestisia (2016).

\subsubsection{Optimum temperature}

Tubes containing the reaction mixture and enzyme extract were incubated at different temperatures of $25,30,35,37,40,45,50,55$, and $60^{\circ} \mathrm{C}$ at the optimum pH for $60 \mathrm{~min}$. The enzyme activity was then assayed at each temperature to determine its transglutaminase optimal temperature.

\subsubsection{Transglutaminase thermal stability}

Thermal stability of obtained transglutaminase was determined by pre-incubating the enzyme at two temperatures $\left(45\right.$ and $\left.50^{\circ} \mathrm{C}\right)$ for $15,30,45,60,90$, 120 , and $240 \mathrm{~min}$, and the samples were placed on ice immediately before measuring the enzyme activity.

\subsubsection{Effect of metal ions and inhibitors}

The effects of $5 \mathrm{mM}$ and $10 \mathrm{mM}$ metal ion of $\mathrm{Na}^{+}$, $\mathrm{K}^{+}, \mathrm{Li}^{+}, \mathrm{Cu}^{+}, \mathrm{Ca}^{2+}, \mathrm{Mg}^{2+}, \mathrm{Zn}^{2+}$, and $\mathrm{Fe}^{3+}$ in the chloride salt solution on enzyme activity was studied (Lin, Hsieh, Lai, Chao, \& Chu, 2008) as well as those of 5 $\mathrm{mM}$ and $10 \mathrm{mM}$ of EDTA (ethylene diamine tetraacetic acid), PMSF (phenyl methyl sulfonyl fluoride), BPB (4-bromo-phenacyl bromide), and the IAA (iodo acetamide acid) (Suzuki et al., 2000). The activity was measured under standard assay condition and the relative activity was calculated as the percentage of 
activity remaining after incubation with various reagents for $60 \mathrm{~min}$ at $50^{\circ} \mathrm{C}$. The relative activity assayed in the absence of additives and without incubation was taken as $100 \%$.

\subsection{Transglutaminase Assay}

The transglutaminase activity was determined by hydroxamate formation with the spesific substrate $N$ Carbobenzoxy-L-Glutaminylglycine (Z-GIn-Gly) (Sigma, Aldrich) according to Folk and Cole (1966), with some modifications. The reaction mixture, containing $100 \mu \mathrm{L}$ of enzyme, $200 \mu \mathrm{L}$ of $0.1 \mathrm{M}$ citrate buffer $\mathrm{pH} 6.0,25 \mu \mathrm{L}$ of $2.0 \mathrm{M}$ Hydroxylamine hydrochloride (Sigma, Aldrich), $25 \mu \mathrm{L}$ of $0.1 \mathrm{M} \mathrm{L}$ Glutathione, reduced form (Sigma, Aldrich), and 75 $\mu \mathrm{L}$ of $0.1 \mathrm{M} \mathrm{N}$-Carbobenzoxy-L-Glutaminylglycine (ZGln-Gly) (Sigma, Aldrich), was incubated at $50^{\circ} \mathrm{C}$ for $60 \mathrm{~min}$ and stopped by adding an equal volume (425 $\mu \mathrm{L}$ ) of $15 \%$ trichloracetic acid containg $5 \% \mathrm{FeCl}_{3}$. The absorbance was measured at $525 \mathrm{~nm}$ (Thermo Scientific). One unit of transglutaminase activity was defined as the amount causing the formation of $1 \mu \mathrm{mol}$ of hydroxamic acid per minute at $50^{\circ} \mathrm{C}$. A calibration curve was prepared using L-glutamic acid $\gamma$ monohydroxamate.

\subsection{Protein Assay}

Protein concentration was measured according to Lowry method (Bollag \& Edelstein, 1991) with bovine serum albumin (BSA) as a standard.

Electrophoresis Zymogram was carried out to determine the molecular weight of the transglutaminase. Electrophoresis was performed using a $10 \%$ separating gel with $1 \%$ substrat and $4 \%$ stacking gel. Prestained Protein Ladder (Base, Singapore) was used to estimate the molecular mass of transglutaminase. To identify the transglutaminase band, after running the electrophoresis, the gel was renaturated in $1 \%$ Triton $\mathrm{X}-100$ at $4{ }^{\circ} \mathrm{C}$ for 2 hours and then incubated with citrate buffer $\mathrm{pH} 6.0$ at temperature of $45^{\circ} \mathrm{C}$ for 8 hours, followed by staining with $\mathrm{FeCl}_{3}$ $5 \%$ in the mini rocker shaker for 2 hours.

\section{Results and Discussion}

\subsection{Purification of Transglutaminase}

After 5 days fermentation, $1 \mathrm{~L}$ of crude enzyme was harvested with specific activity of $0.36 \mathrm{U} / \mathrm{mg}$. After ultrafiltration the specific activity of $100 \mathrm{ml}$ enzyme increased up to $13.15 \%$ with 1.14 fold purity. The increased specific activity of the transglutaminase by ultrafiltration was also reported by Ando et al. (1989) where specific activity of crude extract of transglutaminase from Streptoverticillium S-8112 was $0.13 \mathrm{U} / \mathrm{mg}$ and after concentrated with ultrafiltration, the specific activity reached $0.61 \mathrm{U} / \mathrm{mg}$. In line with these results, Gerber, Jucknischke, Putzien, \& Fuchsbauer (1994) reported that specific activity of transglutaminase produced by Streptoverticillium mobaraense increased from $0.28 \mathrm{U} / \mathrm{mg}$ to $9.0 \mathrm{U} / \mathrm{mg}$ after being concentrated with ultrafiltration. The activity of $40 \mathrm{ml}$ ion exchange fraction was $0.85 \mathrm{U} / \mathrm{mg}$ with yield of $3.83 \%$ and 2.36 fold purity (Figure 1 and Table 1). Further purification was performed by gel filtration chromatography using Sepacryl S-200 column (Figure 2). The result showed that the activity of $120 \mathrm{ml}$ active fraction was $9.78 \mathrm{U} / \mathrm{mg}$. This technique could increase the yield and purification fold up to $1.36 \%$ and 27 fold, respectively. Macedo, Sette, and Sato (2011) reported that purification of the transglutaminase of Streptomyces sp. using Sephadex G-75 column increase yield and fold up to $17.7 \%$ and 5 fold, respectively, while with the same technique, Cui, Du, Zhang, Liu, and Chen (2007) obtained higher result with yield and purification fold were $21.1 \%$ and 30 folds respectively.

Table 1. Purification of the transglutaminase from Streptomyces sp. TTA 02 SDS 14

\begin{tabular}{lccccccc}
\hline Purification steps & $\begin{array}{c}\text { Total } \\
\text { volume } \\
(\mathbf{m L})\end{array}$ & $\begin{array}{c}\text { Total } \\
\text { protein } \\
(\mathbf{m g})\end{array}$ & $\begin{array}{c}\text { Enzyme } \\
\text { activity } \\
\left(\mathbf{U ~ m ~}^{-1}\right)\end{array}$ & $\begin{array}{c}\text { Total } \\
\text { activity } \\
(\text { Unit })\end{array}$ & $\begin{array}{c}\text { Specific } \\
\text { activity } \\
\left(\mathbf{U ~ m g ~ m}^{-1}\right)\end{array}$ & $\begin{array}{c}\text { Yield } \\
(\%)\end{array}$ & $\begin{array}{c}\text { Purification } \\
\text { fold } \\
(\mathbf{x})\end{array}$ \\
\hline Crude Enzyme & 1000 & 2171.81 & 0.774 & 774.00 & 0.36 & 100.00 & 1.00 \\
Ultrafiltration & 100 & 247.80 & 1.018 & 101.80 & 0.41 & 13.15 & 1.14 \\
Q-Sepharose & 40 & 35.00 & 0.741 & 29.64 & 0.85 & 3.83 & 2.36 \\
Sepacryl S-200 & 120 & 1.08 & 0.088 & 10.56 & 9.78 & 1.36 & 27.17 \\
\hline
\end{tabular}




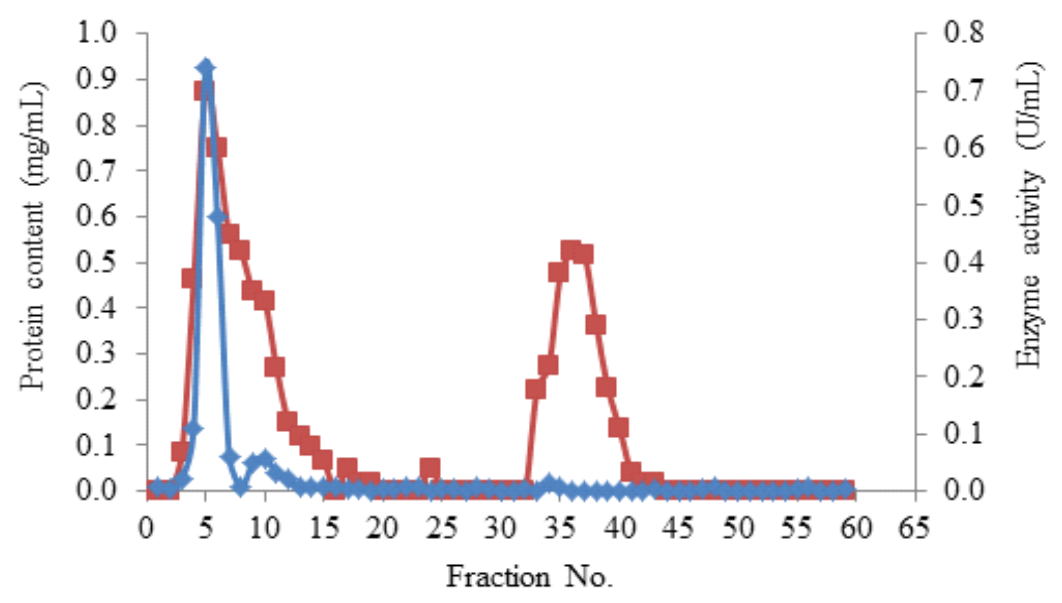

$\neg$ Protein content $(\mathrm{mg} / \mathrm{mL}) \quad-$ Enzyme activity $(\mathrm{U} / \mathrm{mL})$

Figure 1. Ion exchange chromatography profile of transglutaminase produced by Streptomyces sp. TTA 02 SDS 14 using Q-Sepharose column.

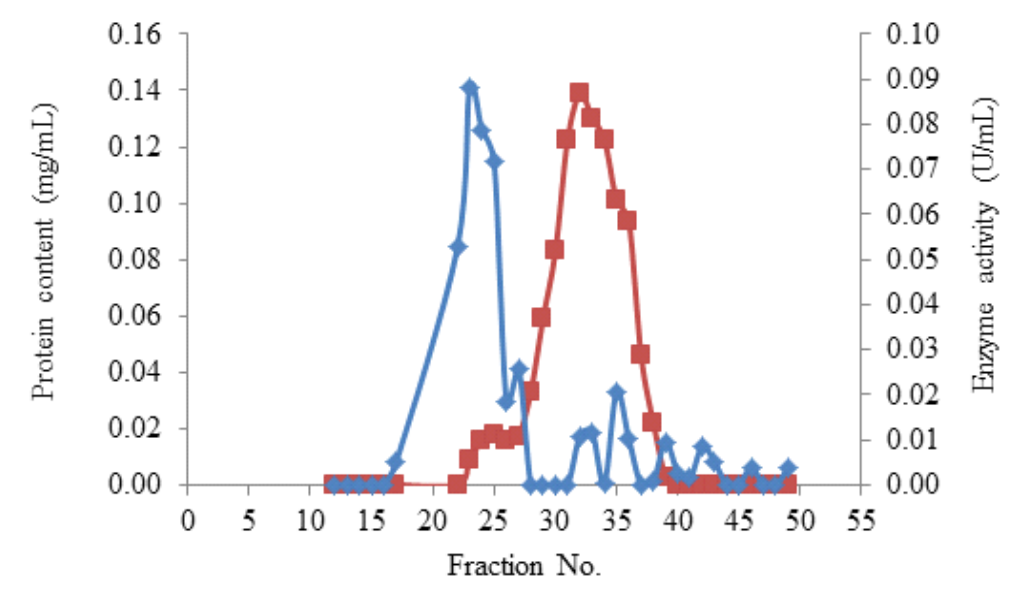

$\neg$ Protein content $(\mathrm{mg} / \mathrm{mL}) \quad \sim$ Enzyme activity $(\mathrm{U} / \mathrm{mL})$

Figure 2. Gel Filtration chromatography profile of transglutaminase produced by Streptomyces sp. TTA 02 SDS 14 using Sepacryl S-200 column.

Purification summary of transglutaminase produced by Streptomyces sp. TTA 02 SDS 14 is showed in Table 1. Figure 1 and Figure 2 showed profile of transglutaminase of Streptomyces sp. TTA 02 SDS 14 fractionated using Q-Sepharose column and Sepacryl S-200 column, respectively.

Protein purification was successfully performed as evidenced by the results of electrophoresis on zymogram. A single band of enzyme activity was seen on polyacrylamide gel electrophoresis containing MTGase substrate. The molecular weight of the enzyme was estimated about $72 \mathrm{kDa}$ (Figure 3). This result shows that the molecular weight of MTGase produced by Streptomyces sp. TTA 02 SDS 14 was much heavier than those from Bacillus subtilis
(29 kDa) (Suzuki et al., 2000), Streptomyces hygroscopicus (38 kDa) (Cui et al., 2007), Streptoverticillium sp. S 8112 (40 kDa) (Ando et al., 1989), Streptomyces platensis YK-2 (45 kDa) (Ko \& Kim, 2009), Streptomyces sp. (45 kDa) (Macedo et al., 2011), Bacillus circulans (45 kDa) (Soares, Assmann, \& Ayub, 2003). However, it is still smaller than those from liver of pig guinea $(90 \mathrm{kDa})$ (Folk \& Cole, 1966) and Oreochromis niloticus (85 kDa) (Worratao \& Yongsawatdigul, 2005).

\subsection{Effect of pH on Enzyme Activity}

The effect of $\mathrm{pH}$ on transglutaminase activity was determined using the reaction mixtures as described 


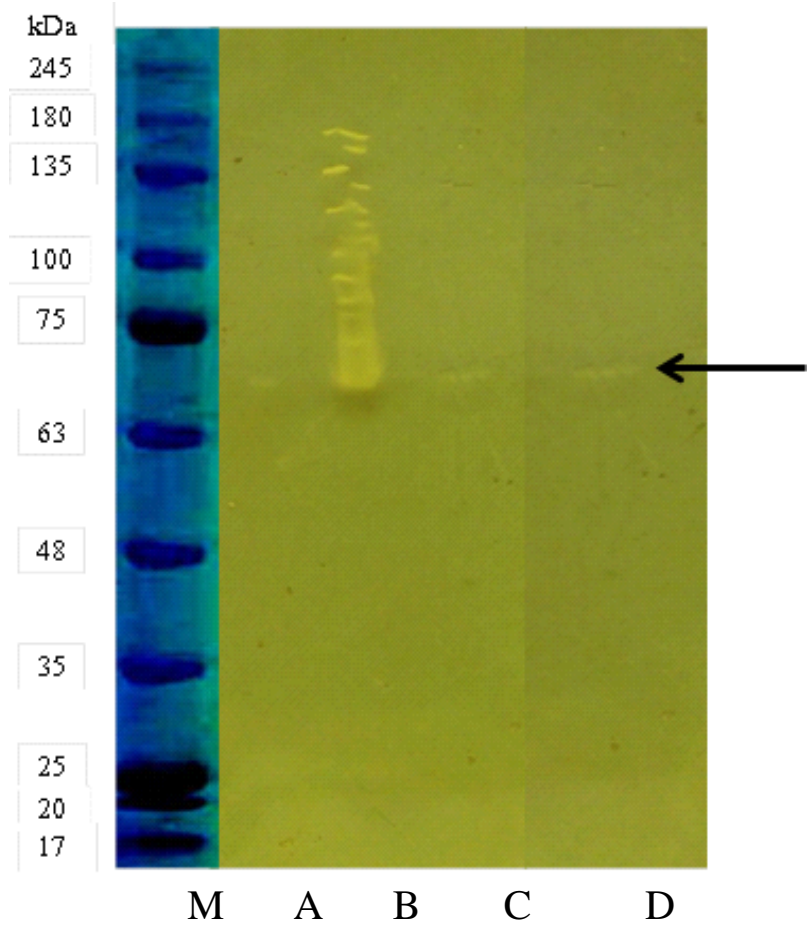

Figure 3. Zymogram of transglutaminase from Streptomyces sp. TTA 02 SDS 14; (M) Standard Marker, (A) Crude Enzyme, (B) Ultrafiltration, (C) Q-Sepharose, (D)Sepacryl S-200.

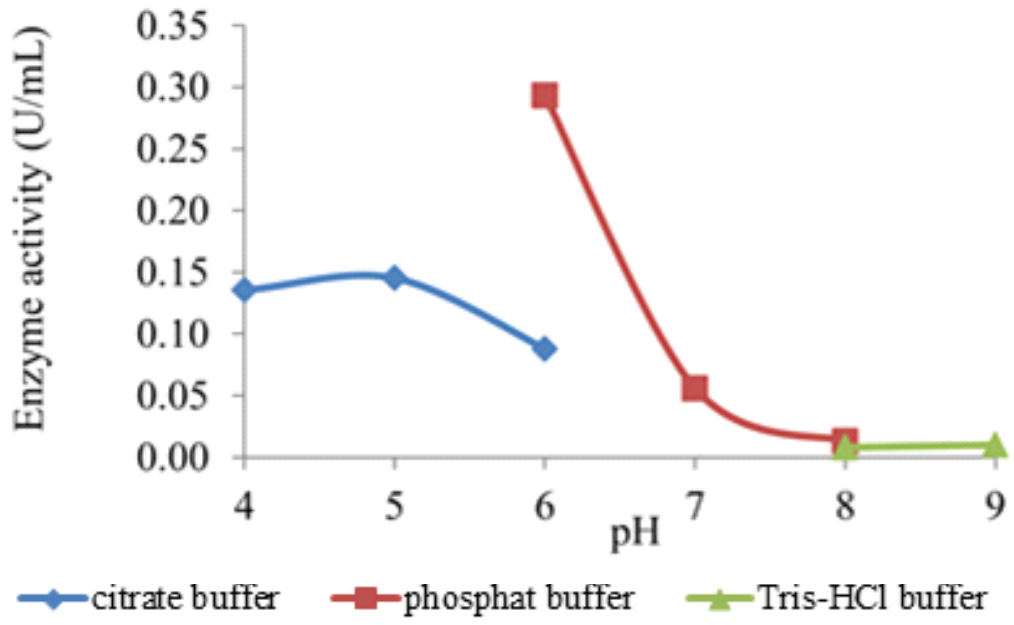

Figure 4. Effect of $\mathrm{pH}$ on the activity of the purified transglutaminase from Streptomyces sp. TTA 02 SDS 14.

previously at $\mathrm{pH} 4-9$ and at $50{ }^{\circ} \mathrm{C}$. The enzyme exhibited optimum activity in phosphate buffer at $\mathrm{pH}$ 6 (Figure 4). The optimum pH of this enzyme was nearly the same as that from Streptoverticillium S8112 with a optimum $\mathrm{pH}$ of 6-7 (Ando et al., 1989), Streptoverticillium ladakanum of 6 (Tsai et al., 1996), Streptomyces sp. of 6-6.5 (Macedo et al., 2011), while Streptomyces hygroscopicus has optimum $\mathrm{pH}$ of 6-7 (Cui et al., 2007). It was different from Bacillus subtilis transglutaminase which has an optimal $\mathrm{pH}$ value of 8.2 (Suzuki et al., 2000). The enzyme from mammals and fishes has a optimum $\mathrm{pH}$ of 8.0 while soybean transglutaminase has an optimal $\mathrm{pH}$ value of 7.6 (Gerber et al., 1994; Worratao \& Yongsawatdigul, 2005). This result confirmed that optimum pHs of MTGase produced by Streptomyces sp. were lower than that produced by Bacillus sp. which were not significantly different with TGase isolated from mammals. 


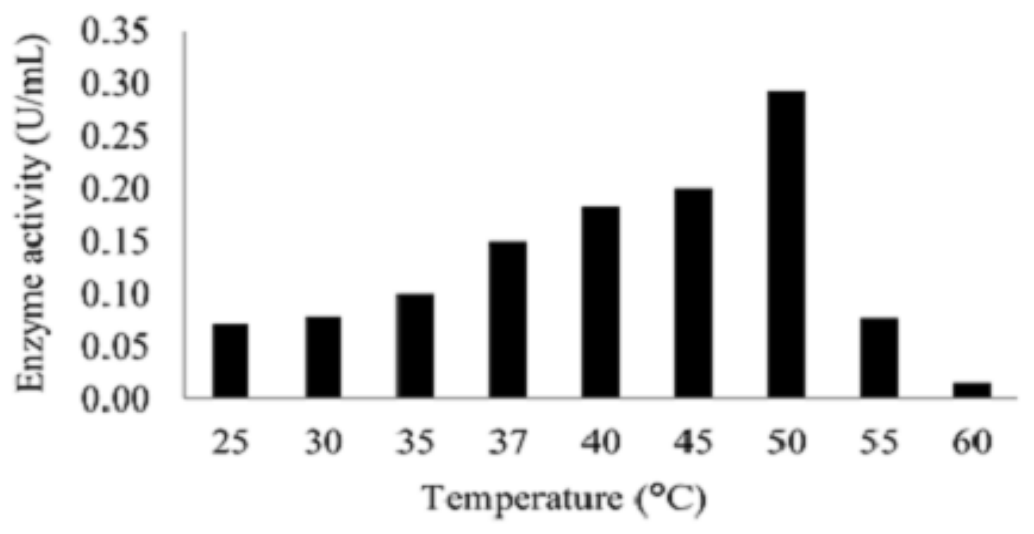

Figure 5. Effect of temperature on the activity of the purified transglutaminase from Streptomyces sp. TTA 02 SDS 14.

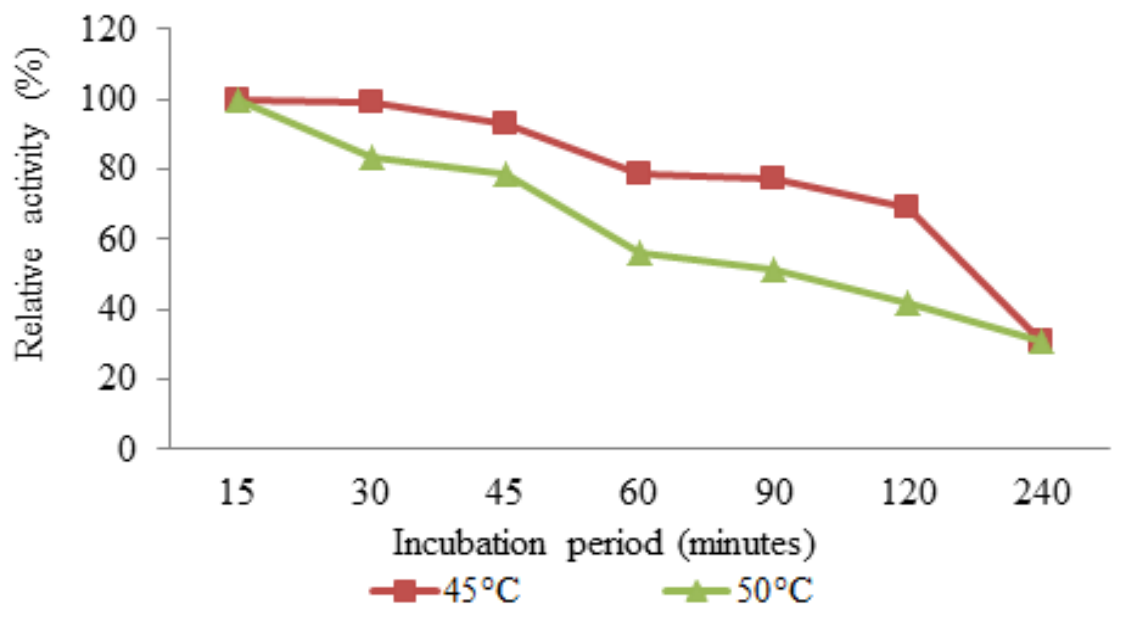

Figure 6. Thermal stability of the purified transglutaminase produced by Streptomyces sp. TTA 02 SDS 14.

Table 2. Effect of metal ions on the transglutaminase produced by Streptomyces sp. TTA 02 SDS 14

\begin{tabular}{lccc}
\hline \multirow{2}{*}{ Metal ion } & \multicolumn{3}{c}{ Relative activity (\%) } \\
& $\mathbf{0} \mathbf{~} \mathbf{M}$ & $\mathbf{5} \mathbf{~} \mathbf{M}$ & $\mathbf{1 0} \mathbf{~} \mathbf{M}$ \\
\hline None & 100 & & \\
$\mathrm{Na}^{+}$ & & 102.23 & 112.49 \\
$\mathrm{~K}^{+}$ & & 96.37 & 115.91 \\
$\mathrm{Li}^{+}$ & & 102.13 & 107.05 \\
$\mathrm{Cu}^{+}$ & & 29.24 & 5.13 \\
$\mathrm{Ca}^{2+}$ & & 96.89 & 115.24 \\
$\mathrm{Mg}^{2+}$ & & 104.25 & 109.95 \\
$\mathrm{Zn}^{2+}$ & & 19.96 & 18.2 \\
$\mathrm{Fe}^{3+}$ & & 94.4 & 98.65 \\
\hline
\end{tabular}

3.3. Effect of Temperature on Enzyme Activity

The enzyme exhibited optimum activity at $50^{\circ} \mathrm{C}$ for the catalytic reaction (Figure 5). Comparing with other transglutaminase from different sources, the optimal temperature of this enzyme was almost similar with that from Streptoverticillium S-8112 (Ando et al., 
Table 3. Effect of inhibitors on the transglutaminase produced by Streptomyces sp. TTA 02 SDS 14

\begin{tabular}{lccc}
\hline \multirow{2}{*}{ Inhibitor } & \multicolumn{3}{c}{ Relative activity (\%) } \\
\cline { 2 - 4 } & $\mathbf{0 ~} \mathbf{~ M ~}$ & $\mathbf{5 ~} \mathbf{~ M}$ & $\mathbf{1 0} \mathbf{~ M}$ \\
\hline None & 100 & & \\
EDTA & & 109.21 & 124.62 \\
PMSF & & 46.24 & 30.55 \\
BPB & & 104.61 & 101.13 \\
IAA & & 293.98 & 206.58 \\
\hline
\end{tabular}

1989) and Streptoverticillium ladakanum (Tsai et al., 1996), which have optimal temperature of $50^{\circ} \mathrm{C}$. However, it was different from that of Rosmarinus officinalis L. (El-Hofi et al., 2014) and Bacillus circulans (Soares et al., 2003) transglutaminases, which have optimal temperature of 55 and $60^{\circ} \mathrm{C}$, respectively. The enzyme activity increased gradually with temperature up to $50^{\circ} \mathrm{C}$, while it declined sharply at temperature over $50^{\circ} \mathrm{C}$.

\subsection{Effect of Thermal Stability on Enzyme Activity}

The thermal stability of the purified transglutaminase was found at $45^{\circ} \mathrm{C}$ and the enzyme retained $69 \%$ of the activity at $45^{\circ} \mathrm{C}$ after 2 hours of incubation in phosphate buffer $\mathrm{pH} 6$, whereas the enzyme retained $50 \%$ after $180 \mathrm{~min}$ of incubation (Figure 6). The thermal stability of this enzyme was nearly the same as that from Streptomyces sp. i.e. at $45^{\circ} \mathrm{C}$ (Macedo et al., 2011; Mahmood, 2013).

\subsection{Effect of Different Metal lons and Inhibitors}

The relative activity of transglutaminase was investigated in the presence of several metal ions and inhibitors, which were added at different concentrations of prepared enzyme and left for $60 \mathrm{~min}$ at $50^{\circ} \mathrm{C}$ (Table 2 and 3 ). The purified transglutaminase was strongly inhibited by the presence of $5 \mathrm{mM}$ and $10 \mathrm{mM}^{\circ} \mathrm{Cu}^{+}$ and $\mathrm{Zn}^{2+}$. However, $\mathrm{Na}^{+}, \mathrm{K}^{+}, \mathrm{Li}^{+}, \mathrm{Ca}^{2+}$, and $\mathrm{Mg}^{2+}$ could increase its activity although not significant (Table 2 ). The presence of metal ions may induce the conformational change of the enzyme which then promotes or reduces its activity depending on amino acid residues displayed in the catalytic centre (Kieliszek \& Misiewicz, 2014). This result is similar to that of Streptoverticillium mobaraense, which was strongly inhibited only by $\mathrm{Zn}^{2+}$, moderately by $\mathrm{Pb}^{2+}$ yet unaffected by $\mathrm{Cu}^{2+}$ (Ando et al., 1989). Cui et al. (2007) reported that transglutaminase of Streptomyces hygroscopicus could be inhibited by $\mathrm{Zn}^{2+}, \mathrm{Cu}^{2+}, \mathrm{Hg}^{2+}, \mathrm{Pb}^{2+}$, and $\mathrm{Fe}^{3+} . \mathrm{Cu}^{2+}$ and $\mathrm{Zn}^{2+}$ and known to preferably react with thiol groups. The strong inhibition of the enzyme by these ions might suggest this enzyme has a thiol group in its active site, similar to transglutaminases from both tissues and other microorganisms (Ando et al., 1989; Ho et al., 2000; Soares et al., 2003).

The purified transglutaminase was not inhibited by EDTA (Table 3), which was completely different from those of calcium dependent transglutaminase from animal tissues or organs (Worratao \& Yongsawatdigul, 2005) and similar to those from microorganism sources (Ando et al., 1989; Ho et al., 2000). Microbial transglutaminase is not influenced by $\mathrm{Ca}^{2+}$, so the presence of metal chelating compounds such as EDTA could not inhibit enzyme activity (Lin et al., 2008). The activity of the purified transglutaminase was inhibited partially by PMSF indicating that active site contained serin (Susanti, 2003; Zilda, 2013). Tsai et al. (1996) reported that transglutaminase produced by Streptoverticillium ladakanum is strongly inhibited by PMSF but not affected by EDTA. The investigation showed that purified transglutaminase was not inhibited by BPB. It means that the histidine which was blocked by BPB did not have role in active site of the enzyme (Tauber, Imbri, \& Opatz, 2014). The results showed that addition of IAA increased the activity up to $206 \%$. It may due to the bound between IAA and histidine at active side cause a better conformational of the enzyme which then can increase the activity.

\section{Conclusion}

This paper reports the purification and characterization of transglutaminase of Streptomyces sp. TTA 02 SDS 14 isolated from savana soil of Tambora mount, West Nusa Tenggara Province, Indonesia. The transglutaminase was purified after being concentrated using ultrafiltration. The purification was conducted using both ion exchange chromatography Q-Sepharose and gel filtration chromatography Sepacryl S-200 so that molecular weight of the enzyme could be estimated around 72 
$\mathrm{kDa}$. The obtained enzyme showed optimum activity in phosphate buffer $\left(\mathrm{pH} \mathrm{6.0)}\right.$, at $50^{\circ} \mathrm{C}$. It was stable at $45^{\circ} \mathrm{C}$ for $2-\mathrm{h}$ incubation. The results showed that the pure transglutaminase could be easily activated by the presence of $5 \mathrm{mM} \mathrm{Na}^{+}, \mathrm{Li}^{+}, \mathrm{Mg}^{2+}$, but inhibited by $\mathrm{Cu}^{+}, \mathrm{Zn}^{2+}$, and PMSF. These characters make enzyme as a good applicant in food industry. However, additional work are required to increase the yield during extraction and purification for commercialization, especially in medical field.

\section{Acknowledgements}

We thanks Ir. Yusro Nuri Fawzya, MSi for the project and Dr. Puspita Lisdiyanti, M.Agr.Chem. for providing Streptomyces sp. TTA 02 SDS 14. This project was financially supported by Research and Development Center for Marine and Fisheries Product Competitiveness and Biotechnology (P3DSPBKP), Ministry of Marine and Fisheries, Indonesia.

\section{References}

Ando, H., Adachi, M., Umeda, K., Matsuura, A., Nonaka M., Uchio, R., Tanaka, H., \& Motoki, M. (1989). Purification and characteristics of a novel transglutaminase derived from Microorganisms. Agricultural \& Biological Chemistry, 53(10), 26132617. doi:10.1080/00021369.1989.10869735.

Bahrim, G., lancu, C., Butu, N., \& Negoita, T. G. (2010). Production of a novel microbial transglutaminase using Streptomyces sp.polar strains. Romanian Biotechnological Letters, 15(2), 5197-5203.

Bollag, D. M., \& Edelstein, S. J. (1991). Protein Method. New York, US: Wiley-Liss, Inc.

Cui, L., Du, G., Zhang, D., Liu, H., \& Chen, J. (2007). Purification and characterization of transglutaminase from a newly isolated Streptomyces hygroscopicus. Food Chemistry, 105, 612-618. doi:10.1016/ j.foodchem.2007.04.020.

El-Hofi, M., Ismail, A., Nour, M., \& Ibrahim, O. (2014). Isolation, purification and characterisation of transglutaminase from rosemary (Rosmarinus officinalis L.) leaves. Acta Scientiarum Polonorum Technologia Alimentaria, 13(3), 267-278. Retrieved from http://www.food.actapol.net/.

Fawzya, Y.N., Dewi, S.Z., Seprianto, Hana, N.P., Puspita, L., \& Kasanah, N. (2016). Screening of Indonesian Streptomyces sp. capable of secreting Transglutaminase (MTGase) and optimization of MTGase production using different growth media. Squalen Bulletin of Marine \& Fisheries Postharvest \& Biotechnology, 11 (1): 13-21.

Folk, J. E., \& Cole, P. W. (1966). Mechanism of action of pig liver transglutaminase. Journal Biological Chemistry, 241(23), 5518-5525.
Gerber, U., Jucknischke, U., Putzien, S., \& Fuchsbauer, H. L. (1994). A rapid and simple method for the purification of transglutaminase from Streptoverticillium mobaraense. Biochemical Journal, 299, 825-829.

Ho, M. L., Leu, S. Z., Hsieh, J. F., \& Jiang, S. T. (2000). Technical approach to simplify the purification method and characterization of microbial transglutaminase produced from Streptoverticillium ladakanum. Journal of Food Science, 65(1), 76-80.

Kieliszek, M., \& Misiewicz, A. (2014). Microbial transglutaminase and its application in the food industry. A review. Folia Microbiology, 59(3), 241-250. doi:10.1007/s12223-013-0287-x.

Klein, J. D., Guzman, E., \& Kuehn, G. D. (1992). Purification and partial characterization of transglutaminase from Physarum polycephalum. Journal of Bacteriology, 174(8), 2599-2605. Retrieved from http://jb.asm.org/.

Ko, H. S., \& Kim, H. S. (2009). Purification and characterization of transglutaminase from a newly isolated Streptomyces platensis YK-2. Journal of the Korean Society of Food Science \& Nutrition, 38(6), 801-806. doi:10.3746/jkfn.2009.38.6.801.

Lin, S. J., Hsieh, Y. F., Lai, L. A., Chao, M. L., \& Chu, W. S. (2008). Characterization and large-scale production of recombinant Streptoverticillium platensis transglutaminase. Journal Industrial Microbiology \& Biotechnology, 35(9), 981-990. doi:10.1007/s10295008-0373-2.

Macedo, J. A., Sette, L. D., \& Sato, H. H. (2011). Purification and characterization of a new transglutaminase from Streptomyces sp. isolated in Brazilian soil. Journal of Food Biochemistry, 35, 1361-1372. doi:10.1111/ j.1745-4514.2010.00456.x.

Mahmood, W. A. (2013). Production of transglutaminase by a local Streptomyces isolate using wheat bran. Jordan Journal of Agricultural Sciences, 9(1), 33-42.

Pasternack, R., Dorsch, S., Otterbach, J., Robenek, I., Wolf, S., \& Fuchsbauer, H. L. (1998). Bacterial protransglutaminase from Streptoverticillium mobaraense, purification, characterization and sequence of the zymogen. European Journal of Biochemistry, 257(3), 570-576.

Prestisia, H. N. (2016). Optimasi produksi dan karakterisasi enzim microbial transglutaminase (MTGase) dari Streptomyces sp. galur TTA 02 SDS 14 [Tesis]. Bogor, ID: Institut Pertanian Bogor.

Ramanujam, M. V., \& Hageman, J. H. (1990). Intracellular transglutaminase (EC 2.3.2.13) in a procaryote : evidence from vegetative and sporulating cells of Bacillus subtilis. 168. FASEB Journal, 4, A2321.

Schmidt, S., Adolf, F., \& Fuchsbauer, H. L. (2008). The transglutaminase activating metalloprotease inhibitor from Streptomyces mobaraensis is a glutamine and lysine donor substrate of the intrinsic transglutaminase. FEBS Letters, 582(20), 3132-3138. doi:10.1016/j.febslet.2008.07.049.

Seprianto, Dewi, S.Z., Fawzya, Y.N., Suharsono, Puspita, L., \& Robert, A.U. (2016). Cloning of a 
transglutaminase gene from Streptomyces thioluteus TTA 02 SDS 14. Squalen Bulletin of Marine \& Fisheries Postharvest \& Biotechnology, 11 (1): 31-36.

Soares, L. H. B., Assmann, F., \& Ayub, M. A. Z. (2003). Purification and properties of a transglutaminase produced by a Bacillus circulans strain isolated from the Amazon environment. Biotechnology \& Applied Biochemistry, 37, 297-299.

Srianta. (2000). Potensi aplikasi transglutaminase dalam industri pangan. Jurnal Teknologi Pangan \& Gizi, 1(2), 76-81.

Susanti, E. V. H. (2003). Isolasi dan karakterisasi protease dari Bacillus subtilis 1012M15. Biodiversitas, 4(1), 12-17.

Suzuki, S., Izawa, Y., Kobayashi, K., Eto, Y., Yamanaka, S., Kubota, K., \& Yokozeki, K. (2000). Purification and characterization of novel transglutaminase from Bacillus subtilis spores. Bioscience, Biotechnology, \& Biochemistry, 64(11), 2344-2351.

Tauber, J., Imbri, D., \& Opatz, T. (2014). Radical addition to iminium ions and cationic heterocycles. Molecules, 19(10), 16190-16222. doi:10.3390/molecules 191016190.
Tellez-Luis, S. J., Uresti, R. M., Ramirez, J. A., \& Vazquez, M. (2002). Low-salt restructured fish products using microbial transglutaminase as binding agent. Journal of the Science Food \& Agriculture, 82(9), 953959. doi:10.1002/jsfa.1132.

Tsai, G. J., Lin, S. M., \& Jiang, S. H. (1996). Transglutaminase from Streptoverticillium ladakanum and application to minced fish product. Journal of Food Science, 61(6), 1234-1238.

Worratao, A., \& Yongsawatdigul, J. (2005). Purification and characterization of transglutaminase from tropical tilapia (Oreochromis niloticus). Food Chemistry, 93(4), 651-658. doi:10.1016/ j.foodchem.2004.09.044.

Zhang, D., Zhu, Y., \& Chen, J. (2009). Microbial tranglutaminase production : understanding the mechanism. Biotechnology \& Genetic Engineering Reviews, 26, 205-222.

Zilda, D. S. (2013). Purification and characterization of thermostable protease produced by Brevibacillus sp. LII isolated from Padangcermin hotspring Lampung [Dissertation]. Yogyakarta, ID: Universitas Gadjah Mada. 